\title{
On the Capital Structure of Real Estate Firms
}

\author{
Jamie Alcock ${ }^{1, \mathrm{~A}}$, Eva Steiner ${ }^{\mathrm{B}}$ and Kelvin Jui Keng Tan ${ }^{\mathrm{C}}$ \\ ${ }^{\mathrm{A}}$ The University of Cambridge, United Kingdom, and The University of \\ Queensland, Australia \\ ${ }^{\mathrm{B}}$ LaSalle Investment Management, United Kingdom \\ ${ }^{\mathrm{C}}$ The University of Queensland, Australia
}

\begin{abstract}
The leverage and debt maturity choices of real estate companies are interdependent, and are not made separately as is often assumed in the literature. We use threestage least squares (3SLS) regression analysis to explore this interdependence for a sample of listed U.S. real estate companies and Real Estate Investment Trusts (REITs) traded between 1973 and 2006. We find substantial differences in the nature of the relationship between leverage and maturity for the two firm types. Leverage is a determinant of maturity for non-REITs, whereas maturity is a determinant of leverage for REITs. We also find that the drivers of capital structure choices in real estate companies and REITs clearly reflect the effects of the REIT regulation.
\end{abstract}

Key words: Leverage, Debt Maturity, Capital Structure, G32, G01

1 Corresponding Author: Department of Land Economy, The University of Cambridge, United Kingdom. Telephone +44 1223337 152, Fax +44 1223337 130, Email jta27@cam.ac.uk. 


\section{Introduction}

Capital structure plays a unique role in the real estate industry due to the suitability of the underlying assets as debt security and the almost unique tax treatment afforded to REITs. All real estate firms, be they REITs or not, must consider at least two dimensions when making capital structure choices: the amount of debt (leverage) and the term of the debt contract (maturity). While several studies have explored the determinants of each of these two dimensions separately, very little is known about the interdependence between them. In this paper we explore the nature of the joint determinants of leverage and maturity in real estate firms.

Traditional capital structure studies tend to focus on either leverage or maturity, implicitly assuming that these are determined separately (Barclay and Smith, 1995; Guedes and Opler, 1996). Some studies consider the influence of maturity on leverage or vice-versa, but only as a control variable in an otherwise single-equation setting (Stohs and Mauer, 1996). However, there is increasing support for a clear interdependence between leverage and maturity. Leland and Toft (1996) argue that optimal leverage is a function of firm risk, expected bankruptcy costs and maturity. Indirectly they argue that firms choose maturity first, then determine the corresponding value-maximising level of leverage. In contrast, Alcock, Finn, and Tan (2010) suggest that firms determine the maturity of a debt issuance only once they have chosen to issue debt. They argue that optimal maturity is a monotonic function of leverage. Barclay, Marx, and Smith (2003) and Johnson (2003), in empirical examinations of the joint nature of leverage and maturity choices in U.S. equities, find support for both functional dependencies. We explicitly focus our analysis on the relationship between leverage and maturity for a sample of listed U.S. real estate companies and Real Estate Investment Trusts (REITs) and find that it is richer than often assumed.

Capital structure choices of real estate companies are of particular interest as these firms can choose between different forms of corporate organisation, each having significant implications for capital structure choices. Under the REIT regime, firms are able to significantly reduce corporate tax liabilities, often to the point of eliminating them altogether. In order to achieve this reduction in corporate tax liabilities, REITs must satisfy certain conditions including distributing the majority of taxable income as dividends, investing a minimum percentage of capital in the real estate sector and maintaining a diversified ownership base ${ }^{2}$.

$\overline{2}$ The exact conditions differ from country to country, see e.g. Lehman and Roth (2010). 
Non-REIT real estate firms are not required to meet these conditions, and do not receive preferential tax treatment. Given that both REITs and non-REITs generally invest in the same underlying asset class, it follows that the real estate industry provides a useful natural experiment on the role of regulation and taxation on capital structure decisions.

We examine the interdependence of the leverage and maturity choices using a threestage least squares (3SLS) regression that controls for the endogeneity between leverage and maturity, along with the likely correlation between the errors of the two simultaneous equations. 3SLS allows us to isolate the separate determinants of leverage and maturity as well as to explore whether leverage influences maturity or vice-versa. We estimate all equations for REITs and non-REITS separately in order to analyse the effect of the REIT regulations on the nature of the relationship between leverage and maturity.

We find that the drivers of capital structure choices in real estate companies and REITs and particularly the differences in the nature of the interdependence between their leverage and maturity choices clearly reflect the effects of the REIT regulation. We find support for the trade-off theory of leverage in non-REITs, and we also find that maturity is a function of leverage for non-REITs. Evidence for a pecking order in REIT capital structure, rather than trade-off theory, is not surprising given the absence of corporate taxes. The support we find for an inverse relationship between maturity and leverage is in line with the theory put forward in Leland and Toft (1996) once we consider adverse selection costs of equity.

In brief, REIT regulation appears to free up scope in the capital structure to pursue more offensive financing strategies such as signalling firm quality to the market and optimising transaction costs, while non-REITs largely seem to focus on the mitigation of tax, agency costs and refinancing risk. Our results suggest that the relationship between leverage and maturity can also be used to moderate the effects of other exogenous financing policies.

This paper proceeds as follows. Section 2 reviews the relevant traditional capital structure literature, Section 3 introduces the functional relationship between leverage and maturity as suggested in Alcock, Finn, and Tan (2010). Section 4 provides details on data and methodology and Section 5 discusses the empirical results of our study. Section 6 concludes. 


\section{Literature review}

Traditional capital structure literature often implicitly assumes independence of leverage and maturity choices. However, Leland and Toft (1996) develop the theory that optimal leverage is a monotonic function of maturity to maximise firm value. In the next section, we present the theory developed in Alcock, Finn, and Tan (2010), who argue that maturity is a monotonic function of leverage to reduce the expected cost of debt. Empirically, Barclay, Marx, and Smith (2003) find that leverage and maturity are substitutes to mitigate the underinvestment problem. Johnson (2003) finds that leverage and maturity are complements to reduce refinancing risk. Research into the joint determination of leverage and maturity in real estate is especially sparse. Giambona, Harding, and Sirmans (2008) study joint leverage and maturity choices in REITs. They find that leverage and maturity appear to be substitutes in the sense of Barclay, Marx, and Smith (2003).

There are two main traditional theories explaining leverage choices in isolation. The trade-off theory posits a value-maximising debt ratio where the marginal bankruptcy costs and tax benefits of debt are equal. ${ }^{3}$ However, REITs are exempt from corporate tax if they distribute $90 \%$ of taxable income as dividends, which nullifies the tax and agency cost shields of debt. Theoretically, Howe and Shilling (1988) assert that in the absence of tax benefits, REITs cannot compete for debt and will favour equity. Similarly, Shilling (1994) argues that REIT value is maximised for equityonly financing. Consistent with expectations, Ghosh, Nag, and Sirmans (1997) find that REITs raise more capital through seasoned equity than debt. Boudry, Kallberg, and Liu (2010) study issuance decisions of REITs. They find that REITs are less likely to issue debt when bankruptcy costs are high and interpret this as support for the trade-off theory. Brown and Riddiough (2003) examine public financial offerings of REITs and find that, consistent with the existence of an optimal leverage ratio implied in trade-off theory, REITs appear to target a leverage ratio. However, this targeting strategy appears to be motivated by the maintenance of an investmentgrade rating.

The pecking order theory ${ }^{4}$ claims that capital structure changes reflect a need for external funds given the higher informational sensitivity and thus adverse selection cost of equity.

\footnotetext{
3 Variations are explored in DeAngelo and Masulis (1980); Jensen (1986); Kraus and Litzenberger (1973) and Modigliani and Miller (1963).

4 See e.g. Donaldson (1961); Myers (1984); Myers and Majluf (1984); Shyam-Sunder and Myers (1999)
} 
However, there are conflicting views on information asymmetry in real estate. Boudry, Kallberg, and Liu (2010) argue that REITs especially are a fairly transparent investment vehicle as they focus on cash yields and stable cash flows from the operation of real estate, thereby questioning the source of any asymmetric information. On the other hand, Han (2006) argues that accurate real estate valuation requires sophisticated local knowledge, thus increasing information asymmetry.

Moreover, pecking order assumes discretion over earnings, debt and equity. However, REIT pay-out requirements restrict funding choices to debt and equity. Accordingly, Boudry, Kallberg, and Liu (2010) find no evidence for pecking order in REIT financing choices. Nevertheless, several studies confirm the negative price and valuation effects of equity issues implied in pecking order (Brounen and Eichholtz, 2001; Ghosh, Nag, and Sirmans, 1999, 2000; Howe and Shilling, 1988). More specifically, Feng, Ghosh and Sirmans (2007) show that REITs balance the lack of incentive for debt and the adverse selection cost of equity.

There are two main theories explaining maturity choices in isolation. Myers (1977) suggests that matching debt and asset maturity helps mitigate underinvestment. However, Kolb (1987) points out that strict adherence to the asset matching principle implies a current ratio of one and thus increased refinancing risk. Hart (1993) posits an inverse relationship between maturity and growth opportunities as short-term debt mitigates underinvestment. Empirics largely support both theories (Barclay and Smith, 1995; Guedes and Opler, 1996; Stohs and Mauer, 1996).

Flannery (1986) develops an inverse relationship between debt maturity and firm quality. High quality is signalled through issuing short-term debt to exploit favourable refinancing terms. The liquidity risk theory (Diamond, 1991; Sharpe, 1991; Titman, 1992) predicts an inverse relationship between credit rating and debt maturity as lower-rated firms attempt to avoid risky refinancing events. Empirically, Guedes and Opler (1996) and Stohs and Mauer (1996) confirm this theory.

Research into maturity choices in real estate is sparse. Howe and Shilling (1988) find REIT stock prices increase after short-term debt issues, confirming the signalling hypothesis. Brown and Riddiough (2003) find a negative relationship between REIT debt maturity and credit ratings, consistent with the liquidity risk theory. Highfield, Roskelley, and Zhao (2007) find little evidence for signalling and liquidity risk in REITs but confirm the influence of personal taxes and agency problems. 


\section{Debt maturity as a function of leverage}

\subsection{Leverage as a function of maturity}

Leland and Toft (1996) examine the optimal capital structure of a firm that can choose leverage and maturity. They argue that optimal leverage is a function of firm risk, expected bankruptcy costs and maturity. Indirectly they argue that firms choose maturity first, then determine the corresponding value-maximising level of leverage. More specifically, they show that the optimal, value-maximising leverage ratio increases with maturity.

\subsection{Debt maturity in the simple Merton framework}

Following Black and Scholes (1973), Merton (1974) develops pricing structures for risky corporate debt in the absence of bankruptcy costs and debt covenants. In Merton's model, the value of risky debt is given by the value of a riskless bond less a European put option on the underlying value of the firm, struck at the face value of debt. Merton illustrates a monotonic relationship between volatility and optimal leverage, and a similar monotonic relationship between volatility and optimal debt maturity. While not explicitly identifying the direct relationship between leverage and maturity, Merton's framework can be used to identify the a clear functional relationship between leverage and optimal maturity of risky debt.

In the Merton framework, the value of a risky zero-coupon bond (ZCB) is given by:

$$
\begin{gathered}
D_{0}=e^{-r_{f} T} X-P_{0}=X e^{-r_{f} T} N\left(d_{2}\right)+V e^{-q T} N\left(-d_{1}\right), \\
\text { where } d_{1}=\frac{\ln \frac{V}{X}+\left(r_{f}-q+\frac{\sigma^{2}}{2}\right) T}{\sigma \sqrt{T}}, \quad d_{2}=d_{1}-\sigma \sqrt{T},
\end{gathered}
$$

where $e^{-r T} \mathrm{X}$ is the face value of the bond discounted at the risk-free rate and the put option ${ }^{5}$ represents the expected losses due to default.

From Merton's valuation of risky debt the default-risk premium, $\lambda$, is given by:

$$
\lambda=-\left(r_{f}+\frac{1}{T} \ln \left[e^{-r_{f} T} N\left(d_{2}\right)+\frac{V}{X} N\left(-d_{1}\right)\right]\right) .
$$

\footnotetext{
5 And where, as per standard notation, $r$ is the risk-free rate of return, $q$ is the continuous dividend, $T$ is the maturity of the bond and $\sigma$ is the volatility of $V$ the value of the firm.
} 
The default-risk premium is a non-linear function of maturity $(T)$, leverage $(X / V)$, volatility $(\sigma)$, and the risk-free rate $\left(r_{f}\right)$. Table 1 presents the risk premium of risky debt calculated for various levels of leverage and maturity in the absence of bankruptcy costs. The risk premium for firms with low leverage is monotonically related to term to maturity. At higher levels of debt, the risk premium for risky debt is negatively related to term to maturity. The total costs of debt (without bankruptcy costs) for both one and two year ZCBs over a 2 year period can be determined from the risk premium in Table 1.

In the absence of bankruptcy costs, the total cost of debt incurred by issuing successive 1 year ZCB is not necessarily greater than the costs incurred by issuing a single 2 year ZCB. The non-linear relationship between maturity, leverage and risk premium, in Table 1, implies that the cheaper debt instrument is determined by the leverage ratio. As illustrated in Figure 1a, a high leverage ratio implies that longer-term debt is cheaper. Conversely, a lower leverage ratio implies a lower cost of debt for the short-term instrument. The expected proportional loss due to default for a highly levered firm appears to dissipate slowly over time. In order to minimise the costs of debt under Merton's assumptions, the debt maturity strategy of firms should be monotonically related to leverage.

[Table 1 about here]

[Figure 1a about here]

Table 1 does not suggest that at some critical leverage ratio, firms should change their optimal maturity from short term debt to long term debt. Rather, Table 1 illustrates the point that when firms with higher pre-issuance leverage issue debt, the new issuance should be longer term debt. Consequently, the duration of the firm's entire debt portfolio will increase slightly. Therefore, the weighted average debt maturity for the firm will monotonically increase with leverage.

This implies that the relationship between debt maturity and debt leverage is monotonic. The leverage level at which crossover occurs is largely insensitive to the level of bankruptcy costs.

[Figure 1b about here] 


\section{Data and Methodology}

We examine the capital structure choices of U.S. listed real estate companies (Standard Industrial Classification (SIC) codes 6500 to 6552) and REITs (SIC code 6798) during the period 1973, the first year for which Compustat has complete debt maturity data, to 2006, the last full year of data prior to the global financial crisis. Our final sample consists of 189 (916) firm-year observations for REITs (non-REITs). All variables except volatility and abnormal earnings are measured at the fiscal year-end prior to the year in which leverage and maturity are measured (Billett, King, and Mauer, 2007; Datta, Iskandar-Datta, and Raman, 2005; Johnson, 2003).

Leverage and maturity choices are commonly investigated in single equation models that do not accommodate for the possibility of joint determination, thereby implicitly assuming exogeneity of predictors and i.i.d. distribution of errors that also have to be unrelated to the regressors. If one of the predictors is not exogenous, single equation results may suffer from omitted variable bias. If errors are not independent, estimates are likely to be inconsistent (simultaneity bias).

We adopt three-stage least squares (3SLS) to investigate the nature of the joint determination of leverage and maturity. 3SLS allows us to estimate the bidirectional effects between leverage and maturity and can achieve a more efficient estimation than two-stage least squares by exploiting cross-equation correlation of errors. Pagan and Hall's (1983) heteroscedasticity tests are performed in each equation and do not indicate the existence of heteroscedasticity.

\section{Proxies for Maturity Hypotheses}

The measurement of debt maturity varies in the literature. Fortunately, Scherr and Hulburt (2001) report that the use of different measurements has little impact on empirical results. We follow Barclay, Marx, and Smith (2003) and use the ratio of a firm's long-term debt (debt due after three years) to total debt as our proxy for maturity.

Following the debt maturity literature (Billett, King, and Mauer, 2007; Datta, Iskandar-Datta, and Raman, 2005; Stohs and Mauer, 1996), we measure leverage by the ratio of total debt (long-term debt plus current liabilities) to market value of assets (book value of assets less book value of common equity plus market value of common equity). 
Two factors complicate the empirical identification of a positive relationship between leverage and maturity as posited in Alcock, Finn, and Tan (2010). First, Figures 3a (non-REITs) and 5a (REITs) show that most firms generally have a high proportion of long-term debt, suggesting that our measurement of long-term debt is conservative. Secondly, the measurements of maturity and leverage in this study (and most other debt maturity studies) are inversely related to each other. Any support for a positive relationship between leverage and maturity or a negative relationship between maturity and leverage will therefore be an underestimate of the strength and direction of the true relationship.

[Figures 3a, 3b, 5a, 5b about here]

Following Highfield, Roskelley, and Zhao (2007) we use the ratio of gross depreciable property to depreciation expense to proxy asset maturity, and transform it using a natural logarithm to correct the skewness of the measure. Growth opportunities are measured by the market-to-book ratio, i.e. the market value of assets divided by the book value of assets (Johnson, 2003). Barclay and Smith (1995) and Barclay, Marx, and Smith (2003) suggest the use of abnormal earnings as a proxy for firm quality, as annual earnings tend to follow a random walk (Kleidon, 1986; Watts and Zimmerman, 1986). We measure abnormal earnings by the difference between earning per share (EPS) in year $t+1$ and EPS in year $t$, divided by the year $t$ share price. Following Stohs and Mauer (1996), we measure firm size by the log of firm market value, deflated by the Producer Price Index (PPI).

[Tables 2 about here]

The slope of the interest rate term structure is measured by the difference between the month-end yields on a 10-year government bond and a 6-month government bond, matched to the month of a firm's fiscal year end. Bond yields have been obtained from the Federal Reserve Bank of St. Louis's Economic Database. Earnings volatility is added to the maturity equation as a measure of credit risk, the effects of which potentially crowd firms with volatile earnings out of the public debt market. Volatility is measured by the standard deviation of first differences in EBITDA over the four years preceding the sample year, scaled by the average assets for that period (Johnson, 2003). Unrated firms tend to have lower credit quality than rated firms and hence are more likely to find difficulty in issuing long term public debt. 
Following Johnson (2003), we include a debt rating dummy (rated=1; otherwise=0) in the maturity equation to control for credit risk. Finally, we include year dummy variables in the debt maturity regression to control for the effects of latent macroeconomic event shock factors.

\section{Proxies for Leverage Hypotheses}

Following the corporate leverage literature ${ }^{6}$, a set of common predictors of leverage are included in the leverage equation. Firms with high growth opportunities should use lower leverage to avoid underinvestment problems (Rajan and Zingales, 1995). The inclusion of abnormal earnings is used to control for signalling effects in leverage choices (Ross, 1977). Larger firms (size) are likely to face lower asymmetric information problems, hence they might use more equity than debt (Myers and Majluf, 1984). Firms with highly volatile earnings (as defined above) use less debt (Bradley, Jarrell, and Kim, 1984).

Fixed-assets ratio is defined as net property, plant, and equipment divided by the book value of assets in the leverage equation. Investors in firms with more tangible assets use leverage to extract information about the relative value of liquidation and to monitor management (Harris and Raviv, 1990; Williamson, 1988). Profitability is defined as the ratio of EBITDA to book value of assets and is used to control for changes in leverage resulting from the (dynamic) pecking order theory (Donaldson, 1961; Myers and Majluf, 1984), which implies that profitable firms use less debt. DeAngelo and Masulis (1980) argue that firms with alternative tax shields have less incentive to utilise tax benefits generated from interest payments. We include investment tax credit as a dummy that equals one in the presence of tax credits and zero otherwise. We also include a net operating losses carried forward dummy that equals one in the presence of carryforwards and zero otherwise.

\footnotetext{
6 For a set of firm characteristics that affect leverage in leverage studies, see Rajan and Zingales (1995), Hovakimian, Opler, and Titman (2001), Fama and French (2002), Hovakimian, Hovakimian, and Tehranian (2004) and Flannery and Rangan (2006).
} 


\subsection{Descriptive Statistics}

Table 2 (Table 3) shows the distribution of debt maturity and leverage between 1973 to 2006 for non-REITs (REITs). REITs tend to borrow longer term debt than non-REITs. REITs might benefit from better access to long-term debt and face fewer refinancing risks. There is no significant difference in the leverage of the two firm types. Figure 2 (Figure 4 ) shows the debt maturity pattern of non-REITs (REITs) over the study period. The main differences are that REIT maturity is more volatile than for non-REITs. Second, non-REIT maturity appears to decrease prior to financial crises, while REIT maturity appears to increase at those times.

Panel B of Tables 2 (non-REITs) and 3 (REITs) presents descriptive statistics for all variables over the study period. Simple $t$-tests are employed to detect statistically significant differences. The mean and median of firm size for non-REITs (\$245.61mil, $\$ 51.63 \mathrm{mil})$ are statistically smaller than those for REITs $(\$ 1,895 \mathrm{mil}, \$ 3.89 .63 \mathrm{mil})$. To minimise any undue influence of outliers, we winsorise the variables at the 1st and 99th percentiles. Non-REITs have average asset maturity of 23.10 years, similar to that of REITs (26.05 years), but both are higher than for industrial firms (Billett, King, and Mauer, 2007) (12.06 years), consistent with the notion that the useful life of real estate assets is very long. Non-REIT growth opportunities (1.42) are higher than for REITs (1.26). Lower growth opportunities in REITs, which are generally viewed as value-stocks, might suggest that some aspects of debt-equity agency conflicts are of lesser concern. REIT earnings volatility (0.04) is significantly lower than for non-REITs (0.06). This is consistent with the view that REITs focus on stable income streams from the operation of real estate (Boudry, Kallberg, and Liu, 2010). REITs have significantly higher fixed assets ratios than non-REITs (0.58 vs. 0.46), which reflects the composition of the non-REIT sample that includes agents and managers who do not own the property. However, we find that the 3SLS results are qualitatively similar when this category (SIC 6531) is excluded. Also, we find significant differences in the proportion of firm-years with alternative tax shields, and REITs have significantly more observations with debt ratings, intuitively consistent with the composition of the non-REIT sample and the corresponding firm sizes.

Tables 4 and 5 present the Pearson correlation matrix among the measures of all dependent and independent variables for the period of 1973 to 2006. The matrix shows low levels of correlation between most independent variables. 


\section{Results}

\subsection{The interdependence of leverage and maturity}

The 3SLS results for the relationships between the leverage and maturity choices of real estate companies and REITs together with their predictors are reported in Table 6 . The 3SLS setting accommodates for the hypothesised endogeneity and simultaneity of leverage and maturity while controlling for the individual leverage and maturity determinants commonly supported in the literature. We find that the drivers of capital structure choices in real estate companies and REITs and particularly the differences in the nature of the interdependence between their leverage and maturity choices clearly reflect the effects of the REIT regulation.

We find that non-REIT debt maturity is positively related to leverage, but we find no support for the reverse, that is, non-REIT leverage is not a function of maturity. Our finding is consistent with major US-equity debt maturity studies (Datta, IskandarDatta, and Raman, 2005; Johnson, 2003; Stohs and Mauer, 1996) and has several implications. First, the unidirectional nature of the relationship suggests that real estate companies determine leverage exogenously and then choose the corresponding maturity. Second, the fact that the relationship is positive supports the hypothesis that, for a given level of leverage, real estate companies choose maturity in order to reduce expected costs of debt in the sense of Alcock, Finn, and Tan (2010). Third, the lack of evidence for the simultaneity theory developed in Barclay, Marx, and Smith (2003) and Johnson (2003), suggests that real estate companies use the leverage and maturity dimensions of capital structure for different purposes rather than regarding them as complements or substitutes.

Conversely, we find that REIT leverage is inversely related to maturity. We find no evidence for a reverse causality. REITs determine maturity exogenously and the corresponding level of leverage follows. At first sight, the direction of this relationship contradicts the theory developed in Leland and Toft (1996), an interesting result, which we examine in detail below. Our results also suggest that REITs employ leverage and maturity for different purposes. Giambona, Harding, and Sirmans (2008) study REIT leverage and maturity choices in a 2SLS setting and find that leverage is inversely related to maturity. In line with Barclay, Marx, and Smith (2003), they also confirm the reverse. The contrast to our results highlights the value of 3SLS in the analysis of potential endogeneity in capital structure choices. 
The lack of evidence for endogeneity between leverage and maturity in both firm types may suggest that unregulated firms have an incentive to choose an optimal target level of leverage first, which is followed by the determination of a corresponding level of maturity. On the other hand, regulated firms do not appear to have an a priori preference for a specific debt level, hence optimal maturity is chosen first, and leverage follows. In this argument, the regulatory situation of a firm would determine the incentive structure for prioritising leverage over maturity choices or vice versa. This finding would imply that leverage and maturity can only be chosen simultaneously if the incentives for prioritising the determination of one dimension over the other exactly offset each other. Only in this case would a firm be able to view leverage and maturity as complements or substitutes, depending on other firm-specific characteristics.

\subsection{The determinants of leverage}

Non-REITs determine leverage first as they have an incentive to follow the trade-off theory and choose an optimal level of leverage to mitigate corporate taxes. We find strong empirical support for the adherence of non-REITs to the trade-off theory, as operating losses carried forward and investment tax credit are significant in the determination of leverage, and investment tax credit correctly carries a negative sign. Contrary to expectations, the operating losses carried forward dummy has a positive sign. This finding is consistent with Johnson (2003) who suggests that firms with losses carried forward have higher leverage as losses reduce relative equity values.

Inconsistent with the trade-off theory, the term structure of interest rates is insignificant in the determination of non-REIT debt maturity. However, previous empirical results for the term structure hypothesis are mixed. Barclay and Smith (1995) find a statistically (not economically) significant positive relationship between term structure and maturity but they do not control for leverage. Guedes and Opler (1996) find a statistically negative relationship. In U.S. studies, and after controlling for leverage, Johnson (2003) and Stohs and Mauer (1996) do not find support for the term structure hypothesis. Our results are consistent with Johnson (2003).

We find no support for a pecking order in the capital structure of real estate companies. In the presence of corporate taxes, real estate companies appear to pursue a more defensive leverage strategy and target a long-term optimal capital structure, trading off means to mitigate corporate taxes and bankruptcy costs of debt. 
The evidence we find for the trade-off theory in non-REITs is consistent with the positive relationship we confirm between leverage and maturity. The target level of leverage resulting from trade-off considerations determines the appropriate maturity to manage the ensuing cost of debt.

In the absence of corporate taxes on the other hand, REITs have no a priori preference for an optimal target level of debt. REITs do not follow the trade-off theory. The alternative tax shield dummies are insignificant in their capital structure choices. Consistent with non-adherence to the trade-off theory, the term structure of interest rates is also insignificant in REIT maturity choices. Brick and Ravid (1985) develop their theory on the basis that the corporate tax rate exceeds the personal tax rate. Therefore, our finding is appropriate as the tax-exempt status of REITs renders accelerated tax benefits through higher long-term interest rates largely obsolete.

We find that REITs follow the more offensive pecking order to actively secure the cheapest funds based on their level of asymmetric information content. This finding is in line with Feng, Ghosh, and Sirmans (2007) and Giambona, Harding, and Sirmans (2008). However, contrary to expectations based on an inverse relationship between firm size and the severity of asymmetric information problems (Myers and Majluf, 1984), it carries a positive sign. Larger REITs use more leverage.

Boudry, Kallberg, and Liu (2010) argue that REITs are fairly transparent as they tend to focus on high yields from operations rather than capital appreciation, which stabilises cash flows. The authors question the source of any asymmetric information in REITs and thus the applicability of the pecking order theory. Our findings suggest that the inherent lack of transparency in real estate as an asset class (Han, 2006) generates the asymmetric information that underlies the pecking order theory. This problem is likely to be exacerbated for larger REITs, possibly with a diversified asset base. When there are no corporate taxes, the information asymmetry resulting from the detailed local market knowledge required to accurately value real estate assets appears to be a strong driver of capital structure given that it remains significant although the regulatory pay-out requirement restricts discretion over retained earnings, normally a fundamental assumption of pecking order.

Apart from adhering to the trade-off theory in an attempt to mitigate corporate taxes, the leverage choices of non-REITs are further driven by a number of similarly defensive objectives, albeit with a focus on the mitigation of debt-related agency costs. 
Growth opportunities and highly volatile earnings induce a reduction in non-REIT leverage so as to mitigate agency costs of underinvestment as well as bankruptcy costs and agency costs of debt in the sense of Bradley, Jarrell, and Kim (1984). In line with Harris and Raviv (1990) and Williamson (1988), our findings suggest that non-REITs with higher proportions of tangible assets carry more debt as they tend to have higher liquidation values. Managers respond to perceived investor preferences to use debt to generate information about when liquidation is more lucrative than ongoing operations as well as to monitor management. Consistent with our interpretation of non-REIT capital structure choices as defensive, we find no support for the more offensive signalling theory (Flannery, 1986; Ross, 1977), as firm quality carries the expected sign but is insignificant in the determination of leverage and maturity.

In contrast, and as already hinted through the adherence to the pecking order, the leverage choices of REITs follow a distinctly more offensive pattern. In line with Howe and Shilling (1988), we find strong support for the signalling hypothesis, as abnormal earnings carry a positive sign and are highly significant. In contrast to real estate companies, REITs signal their quality to the market by issuing more debt when mimicking this strategy is too costly for poor-quality firms. However, REITs use only the leverage dimension of capital structure for signalling purposes and employ maturity to pursue different objectives.

REITs also use leverage to mitigate agency costs - but on a very selective basis. This is consistent with the argument that REITs suffer from fewer agency cost problems as a result of their tight regulation. Consequently, we do not find support for a positive relationship between leverage and the proportion of tangible assets (Harris and Raviv, 1990; Williamson, 1988). In contrast to real estate companies, REIT managers do not feel the need to respond to an investor preference for debt.

Smith (1986) argues that managers of regulated firms have less discretion over investment decisions, which improves investor insight into operations. Unlike for unregulated real estate companies, the regulated status of REITs reduces the value of information and thus the incentive for investors to employ debt as a mechanism to extract it. Rather, it appears that REITs employ leverage choices largely to mitigate growth- and volatility-related agency costs of debt. 
However, REITs employ only the leverage dimension of capital structure for the mitigation of growth-related agency costs. In contrast, they employ both dimensions to mitigate volatility-related agency costs. Boudry, Kallberg, and Liu (2010) point out that REITs are generally characterised by stable cash flows as they focus on the yield from operations. Against this background, our results suggest that earnings volatility is a strong driver of capital structure choices in terms of leverage and maturity, as it stands in contrast to the typical REIT business model.

\subsection{The determinants of maturity}

Non-REIT maturity choices appear to be mainly driven by asset-matching and the link to leverage in the sense of Alcock, Finn, and Tan (2010). These two findings are directly related. According to Kolb (1987), a strict observation of the matching principle implies a current ratio of one, thereby increasing refinancing risk during times of limited debt availability. Firms observing the leverage-maturity relationship put forward in Alcock, Finn, and Tan (2010) will also benefit from increased protection from credit supply shocks. Firms that are at greatest risk from credit supply shocks are firms that are highly levered with substantial short-term debt. If firms with high leverage follow the 'default-risk' theory, they will choose long-term debt and so reduce refinancing risks. Similarly, firms with short-term debt will have chosen short term debt because they have low leverage. Firms with low leverage also face lower refinancing risks when confronted with credit supply shocks. This is not surprising as the inability of a firm to refinance can be thought of a special case of default. In this way, the 'default-risk' model can also be thought of as a 'refinancerisk' model. Real estate companies have an added incentive to adhere to the positive relationship between leverage and maturity so as to mitigate the refinancing risk that partly results from the adherence to the asset matching principle.

The secure provision of funding for new projects and the management of refinancing risk appear to dominate the maturity choices of real estate companies to the extent of rendering most other traditional maturity theories insignificant. Contrary to a number of US debt maturity studies, including Barclay and Smith (1995); Datta, Iskandar-Datta, and Raman (2005); Johnson (2003) and Billett, King, and Mauer (2007), credit rating is insignificant as a predictor for maturity in our study. In a 3SLS setting, it becomes apparent that the positive leverage-maturity relationship dominates the management of refinancing risk. 
Overall, real estate companies appear to pursue a more defensive maturity strategy to ensure funding liquidity and manage refinancing risk, partly resulting from their adherence to the asset-matching principle.

Contrary to Hart (1993), the maturity choices of real estate companies appear to be positively related to the market-to-book ratio. We read this as a direct result of the interaction between leverage and maturity, and it also appears to be the one instance in which we find non-REITs to pursue a more offensive capital structure strategy, albeit indirectly.

Consistent with theory and as reported above, we find support for an inverse relationship between non-REIT growth opportunities and leverage so as to mitigate agency costs of underinvestment. However, we also find evidence that, once leverage decreases, non-REITs shorten maturity accordingly so as to reduce expected costs of debt and refinancing risk in the sense of Alcock, Finn, and Tan (2010).

According to Barclay, Marx, and Smith (2003), leverage and maturity are substitutes in the management of the underinvestment problem. Bearing in mind the positive relationship identified between leverage and maturity, non-REIT capital structure would naturally tend to over-correct maturity with respect to growth opportunities if both these dimensions of capital structure were to be reduced. If this over-correction is allowed to run its course, firms find themselves with low levels of leverage but also with unnecessarily short maturities.

There are two main risks surrounding unnecessarily short maturities, refinancing risk (the risk of not obtaining new funding) and the transaction costs involved in sourcing new funding. The refinancing risk component is mitigated through the leveragematurity relationship. Non-REITs only use short-maturity debt if their leverage levels are sufficiently low. Therefore, given that refinancing risk is controlled, nonREITs have an opportunity here to indirectly reduce transaction costs in the sense of Titman and Wessels (1988) by swapping short-term debt for equity.

Our interpretation in terms of a more opportunistic capital structure strategy is further substantiated by the fact that a high market-to-book ratio can be interpreted as a measure of strong growth opportunities but also as a measure of a high priceto-NAV ratio and thus as an indicator that equity is relatively over-priced in the public market, a situation that offers an incentive to decrease leverage following the argument presented in Boudry, Kallberg, and Liu (2010). 
The interpretation we suggest here can be reconciled with the lack of direct support for the transaction cost-based argument of Titman and Wessels (1988) when we assume that there is an incentive to optimise transaction costs irrespective of firm size - but only once i) higher-priority, more defensive objectives such as the management of underinvestment problems and refinancing risks have been achieved, which is in line with the gerneal pattern we tend to find in non-REIT financing choices, and ii) once maturity would otherwise fall below a certain threshold level.

Unlike real estate companies, REITs do not seem to follow the most common theory of debt maturity. We do not find support for the asset matching principle so as to ensure funding liquidity for new projects. The argument put forward in Kolb (1987) implies that a looser observation of the matching principle indirectly acts as a tool to mitigate refinancing risk. This argument is in line with the finding that REITs do not appear to feel the need to match maturity to their chosen level of leverage so as to (indirectly) reduce refinancing risk.

REITs appear to be less focused on the management of refinancing risk in general. We do not find support for a positive relationship between REIT debt rating and debt maturity either. Again, we can attribute this result to the regulatory situation of REITs. Barclay and Smith (1995) argue that regulated firms can borrow longer term debt because they face fewer debt-related agency problems. The regulation of REITs appears to be a stronger indicator of access to long-term debt than credit ratings and thus helps manage refinancing risk.

In contrast to our results for real estate companies, we find strong support for the size- and transaction cost-based theory of debt maturity (Titman and Wessels, 1988). Larger REITs actively employ capital structure choices to exploit economies of scale and optimise transaction costs by extending debt maturity.

This last insight allows us to explain the unusual inverse relationship between REIT maturity and leverage. If REIT size increases, both maturity and leverage increase, maturity by an opportunistic transaction cost argument, and leverage by the pecking order argument outlined above. So, for a one unit increase in firm size, REITs will eventually hold more debt and this debt is longer term. The increase in maturity is not unwelcome, but in the absence of corporate taxes REITs do not have an incentive to use that much debt (Feng, Ghosh, and Sirmans, 2007). 
It appears that in this case, REITs follow an opportunistic cherry-picking strategy - benefit from lower transaction costs that result from larger firm size if managers subsequently increase maturity, but limit the increase in leverage resulting from the stronger information asymmetry - a by-product of larger firm size. If we view maturity and leverage as substitutes in the management of these information asymmetry-related costs, along the lines of Barclay, Marx, and Smith (2003), then the simultaneous increase in leverage and maturity for a one unit increase in firm size overcorrects the capital structure with regard to what is required to mitigate the higher asymmetry.

Leverage can then be reduced, conserving the beneficial impact of higher maturity on transaction costs. Again, this strategy is predicated on the lack of any a priori preference for a target debt level of REITs; leverage can be adjusted as a function of a variety of factors. Further, in the Leland and Toft (1996) framework, firm value also depends on bankruptcy costs. For REITs, the reduction in leverage is still in line with their rationale, only that in this particular instance, firm value is maximised by reducing leverage relative to maturity through reducing bankruptcy costs.

Overall, the capital structure choices of REITs appear to be more offensive than those of real estate companies as the regulatory setting renders the mitigation of corporate taxation obsolete, reduces agency conflicts, helps manage refinancing risk and thus frees up flexibility in the capital structure to signal firm quality and optimise transaction costs. Again, our results suggest that the relationship between leverage and maturity can also be used to moderate the effects of other exogenous financing policies.

\section{Summary and conclusion}

The contribution of this research to the existing capital structure literature is threefold. First, against the background of increasing theoretical support and empirical evidence for a functional relationship between leverage and maturity choices, we focus our analysis explicitly on the joint determination of these two dimensions of capital structure in real estate firms. We find that this relationship is much richer than often assumed. Second, we contrast and compare the capital structure choices of REITs and non-REITs so as to illustrate the effects of regulation and taxation. We find that the effects of the REIT regulation indeed appear to have a significant impact on capital structure choices. 
Third, our analysis is carried out in a 3SLS setting, which allows us to accommodate for any joint determination of leverage and maturity while improving the efficiency of our estimates. The differences in our results to previous studies highlight the value of 3SLS in exploring the interrelationship between leverage and maturity choices.

In summary, REITs seem to use the leverage dimension of capital structure to follow the pecking order and secure cheaper funds, to actively signal firm quality and to mitigate growth- and especially volatility-related agency costs. Equity-related agency costs explain the inverse relationship between leverage and maturity. REIT maturity choices appear to be mainly targeted at mitigating underinvestment problems and exploiting economies of scale.

Unregulated real estate companies on the other hand have a higher exposure to debtrelated agency costs and are therefore more defensive in their capital structure. In line with the trade-off theory, they focus on the mitigation of corporate taxes, which implies that they prioritise the choice of a target level of leverage. This finding is consistent with the positive relationship we confirm between leverage and maturity. Non-REITs appear to largely tailor their capital structure choices to the timely provision of funding for new projects, the management of debt-related agency costs and the reduction of refinancing risk for a chosen level of leverage.

Generally, our results suggest that, in addition to the interpretation of leverage and maturity as substitutes or complements, the relationship between leverage and maturity can also be used to moderate the effects of other exogenous financing policies.

Howe and Shilling (1988) argue that REITs cannot compete for debt as they cannot benefit from the tax shields offered by interest payments. It has long puzzled researchers why REITs still use debt, and in some cases substantially higher leverage ratios than unregulated real estate companies. Our findings suggest that the regulatory setting and tax-exempt status of REITs provides sufficient flexibility in the capital structure to exploit the benefits of a more offensive strategy and to offset the comparatively higher net cost of debt. 


\section{References}

Alcock, J., F. Finn, And K. J. K. TAN (2010): "What determined the debtmaturity decisions of Australian firms prior to the Global Financial Crisis?," Working paper.

Barclay, M. J., L. M. Marx, and C. W. Smith (2003): "The joint determination of leverage and maturity.," Journal of Corporate Finance, 9(2), 149-167.

Barclay, M. J., AND C. SMith (1995): "The maturity structure of corporate debt.," Journal of Finance, 50(2), 609-631.

Billett, M. T., T.-H. D. King, And D. C. Mauer (2007): "Growth opportunities and the choice of leverage, debt maturity, and covenants.," The Journal of Finance, 62(2), 697-730.

Black, F., AND M. Scholes (1973): "The pricing of options and corporate liabilities.," Journal of Political Economy, 81(3), 637-654.

Boudry, W. I., J. G. KallberG, And C. H. Liu (2010): "An Analysis of REIT Security Issuance Decisions," Real Estate Economics, 38(1), 91-120.

Bradley, M., G. Jarrell, And E. Kim (1984): "On the existence of an optimal capital structure: theory and evidence.," Journal of Finance, 39(3), 857-878.

BRICK, I. E., AND S. A. RAVID (1985): "On the relevance of debt maturity structure.," Journal of Finance, 40(5), 1423-1437.

Brounen, D., And P. M. A. Eichholtz (2001): "Capital Structure Theory: Evidence from European Property Companies," Real Estate Economics, 29, 615-632.

Brown, D. T., And T. J. Riddiough (2003): "Financing Choice and Liability Structure of Real Estate Investment Trusts," Real Estate Economics, 31(3), 313346.

Datta, S., M. Iskandar-Datta, And Raman (2005): "Managerial stock ownership and the maturity structure of corporate debt.," The Journal of Finance, 60(5), 2333-2350.

DeAngelo, H., And R. Masulis (1980): "Optimal capital structure under corporate and personal taxation.," Journal of Financial Economics, 8(1), 3-29.

Diamond, D. (1991): "Debt Maturity Structure and Liquidity Risk," Quarterly Journal of Economics, 106, 709737.

Donaldson, G. (1961): "Corporate debt capacity: a study of corporate debt policy.," Harvard Graduate School of Business.

FAma, E. F., AND K. R. French (2002): "Testing tradeoff and pecking order predictions about dividends and debt.," The Review of Financial Studies, 15(1), $1-33$.

Feng, Z., C. Ghosh, and C. Sirmans (2007): "On the Capital Structure of Real Estate Investment Trusts (REITs)," Journal of Real Estate Finance and Economics, 34, 81-105.

FlanNery, M. J. (1986): "Asymmetric information and risky debt maturity choice.," Journal of Finance, 41(1), 19-37.

Flannery, M. J., AND K. P. Rangan (2006): "Partial adjustment toward target capital structures.," Journal of Financial Economics, 79(3), 469-506.

Ghosh, C., R. Nag, and C. Sirmans (1997): "Financing Choice by Equity REITs in the 1990s," Real Estate Economics, 14(3), 41-50.

(1999): "An Analysis of Seasoned Equity Offerings by Equity REITs, 1991 to 1995," Journal of Real Estate Finance and Economics, 19, 175-192.

(2000): "A Test of the Signaling Value of IPO Underpricing with REIT IPO-SEO Pairs," The Journal of Real Estate Finance and Economics, 20, 137- 
154.

Giambona, E., J. P. Harding, and C. Sirmans (2008): "Explaining the variation in REIT capital structure: the role of asset liquidation value.," Real Estate Economics, 36(1), $111-137$.

Guedes, J., AND T. OpleR (1996): "The determinants of the maturity of corporate debt issues.," Journal of Finance, 51(1), 1809-1833.

HAN, B. (2006): "Inside Ownership and Firm Value: Evidence from Real Estate Investment Trusts," The Journal of Real Estate Finance and Economics, 32, 471493.

HARRIS, M., AND A. RAVIV (1990): "Capital structure and the informational role of debt.," Journal of Finance, 45(2), 321-349.

Hart, O. (1993): Theories of Optimal Capital Structure: A Managerial Discretion Perspective. Washington, DC: The Brookings Institution.

Highfield, M. J., K. D. Roskelley, and F. Zhao (2007): "The Determinants of the Debt Maturity Decision for Real Estate Investment Trusts," Journal of Real Estate Research, 29(2), 173-199.

Hovakimian, A., G. Hovakimian, and H. Tehranian (2004): "Determinants of target capital structure: The case of dual debt and equity issues.," Journal of Financial Economics, 71, 517-540.

Hovakimian, A., T. Opler, And S. Titman (2001): "The debt-equity choice.," Journal of Financial and Quantitative Analysis, 36(1), 1-24.

Howe, J., AND J. Shilling (1988): "Capital Structure Theory and REIT Security Offerings," The Journal of Finance, 43, 983993.

Jensen, M. C. (1986): "Agency costs of free cash flow, corporate finance, and takeovers.," The American Economics Review, 76(2), 323-329.

Johnson, S. A. (2003): "Debt maturity and the effects of growth opportunities and liquidity risk on leverage.," Review of Financial Studies, 16(1), 209-236.

KLEIDON, A. (1986): "Variance bounds tests and stock price valuation models.," Journal of Political Economy, 94(5), 953-1001.

Kolb, R. (1987): Financial management. Glenview: Scott Foresman and Company.

Kraus, A., And R. H. Litzenberger (1973): "A State-Preference Model of Optimal Financial Leverage," The Journal of Finance, 28(4), 911-922.

Lehman, R., And H. Roth (2010): "Global Real Estate Investment Trust Report 2010 - Against all odds," Ernst \& Young LLP.

Leland, H., AND K. Toft (1996): "Optimal capital structure, endogenous bankruptcy, and the term structure of credit spreads.," Journal of Finance, 51(3), 987-1019.

Merton, R. (1974): "On the pricing of corporate debt: the risk structure of interest rates.," Journal of Finance, 29(2), 449-470.

Modigliani, F., AND M. Miller (1963): "Corporate income taxes and the cost of capital: a correction.," American Economic Review, 53(3), 433-443.

MYers, S. (1977): "Determinants of corporate borrowing.," Journal of Financial Economics, 5(2), 147-275.

(1984): "The capital structure puzzle.," Journal of Finance, 39(3), 575-592.

Myers, S., AND N. MAJluf (1984): "Corporate financing and investment decisions when firms have information that investors do not have.," Journal of Financial Economics, 13(2), 187-221.

PAgAn, A. R., AND A. D. HAll (1983): "Diagnostic tests as residual analysis.," Econometric Reviews, 2(2), 159-218.

RAJAN, R., AND L. Zingales (1995): "'What do we know about capital structure?" some evidence from international data.," Journal of Finance, 50(5), 1421-1460. 
Ross, S. A. (1977): "The determination of financial structure: the incentivesignalling approach.," The Bell Journal of Economics, 8(1), 23-40.

Scherr, F. C., And H. M. Hulburt (2001): "The debt maturity structure of small firms.," Financial Management, 30(1), 85-111.

Sharpe, S. (1991): "Credit rationing, concessionary lending and debt maturity structure.," Journal of Banking and Business, 15(3), 581-604.

Shilling, J. D. (1994): "Taxes and the Capital Structure of Partnerships, REITs, and Other Related Entities," Working Paper, University of Wisconsin.

ShyAm-Sunder, L., AND S. Myers (1999): "Testing static tradeoff against pecking order models of capital structure.," Journal of Financial Economics, 51(2), 219244.

Smith, C. W. (1986): "Investment banking and the capital acquisition process.," Journal of Financial Economics of Transition, 15(1-2), 3-29.

Stohs, M., And D. C. Mauer (1996): "The determinants of corporate debt maturity structure.," Journal of Business, 69(3), 279-312.

Titman, S. (1992): "Interest Rate Swaps and Corporate Financing Choices," Journal of Finance, 47, 1503-1516.

Titman, S., And R. Wessels (1988): "Determinants of capital structure.," Journal of Finance, 43(1), 1-19.

Watts, R., And J. Zimmerman (1986): Positive accounting theory. N.J- PrenticeHall, Englewood Cliffs.

Williamson, O. E. (1988): "Corporate finance and corporate governance.," The Journal of Finance, 43(3), 567-591. 


\section{Figures and Tables}

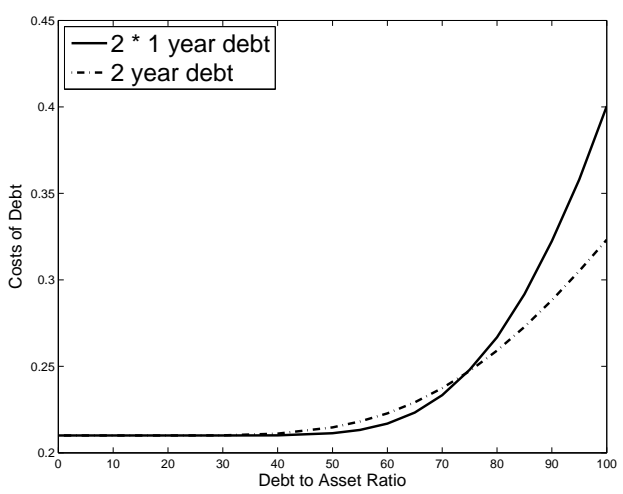

(a) Without Bankruptcy Costs

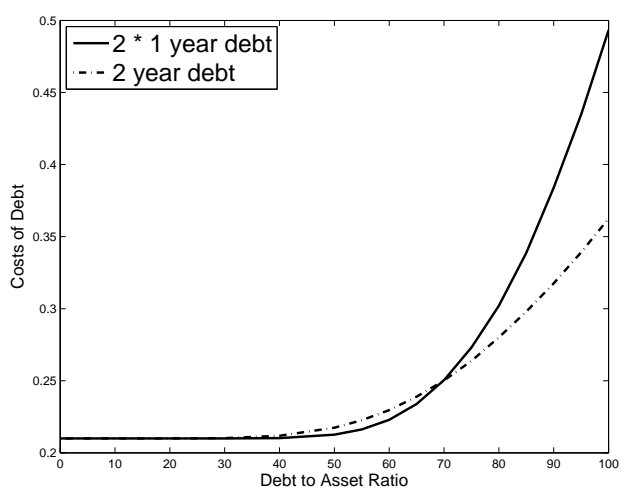

(b) With 10\% Bankruptcy Costs

Fig. 1. Figure 1 compares the total costs (from Table ??) of issuing two different maturity of zero coupon bonds (ZCBs) over a 2 year period. The solid line plots the total costs of issuing two successive 1 year ZCBs while the dotted line plots the total costs of issuing one single 2 year ZCB for various levels of debt leverage. Figure 1a and $1 \mathrm{~b}$ graphically illustrate the difference between these two debt maturity strategies for no bankruptcy costs firms and firms with simulated bankruptcy costs of $10 \%$, respectively. 


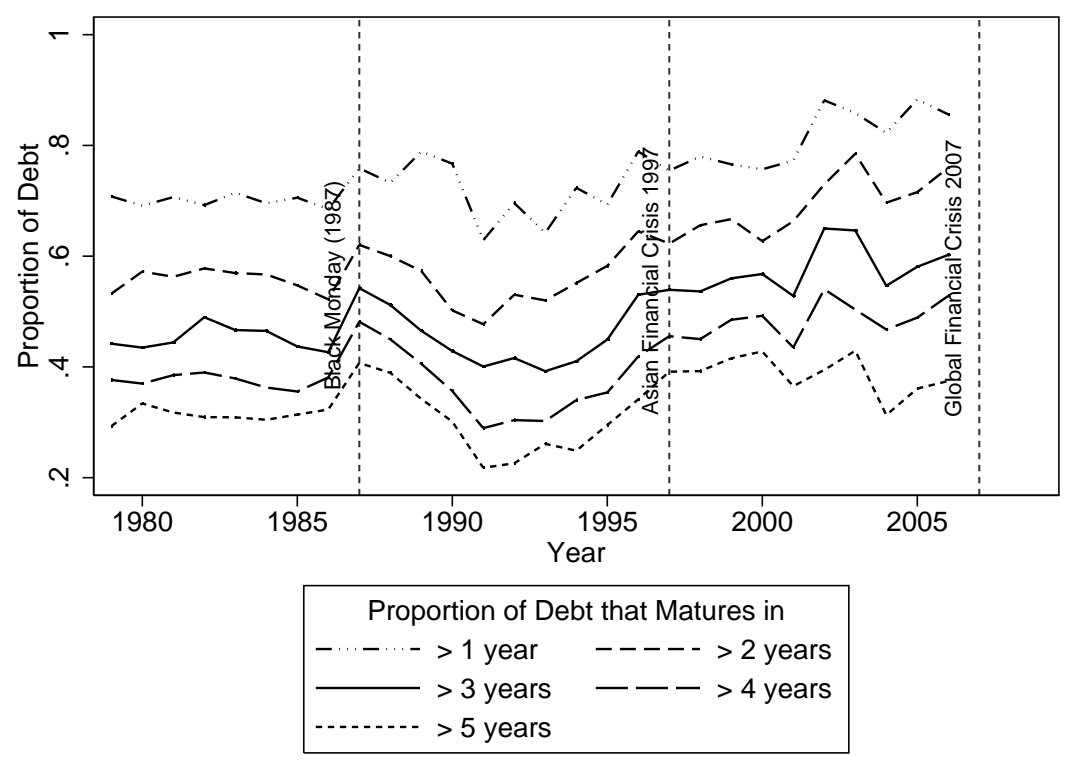

Fig. 2. Cross-sectional view of the proportion of debt that matures in more than one, two, three, four and five years from the fiscal year end for non-REITs.

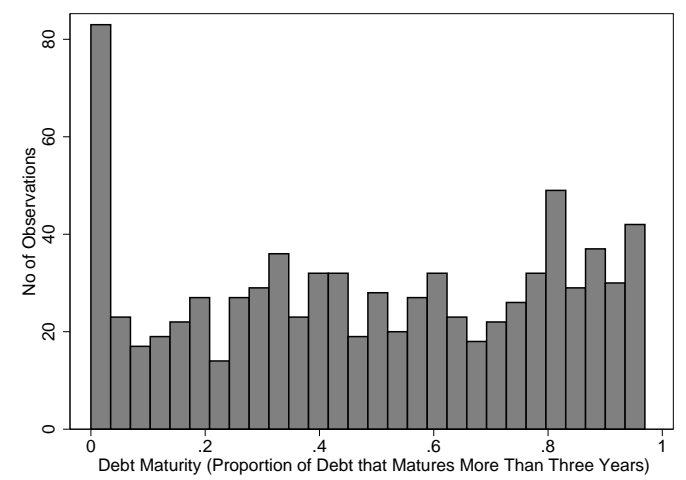

(a) Debt Maturity Histogram for non-REITs

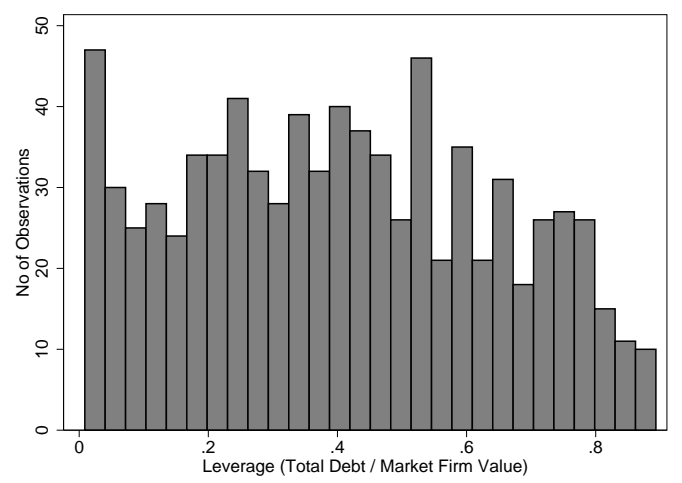

(b) Leverage Histogram for non-REITs

Fig. 3. Histograms of debt maturity and leverage are plotted using 916 firm-year observations for non-REITs over 1973 and 2006 from Compustat Database, in Figure 3a and in Figure 3b, respectively. Histogram of debt maturity (Figure 3a) shows the distribution of debt maturity, measured by the proportion of long-term debt (due more than three years) to total debt. Histogram of leverage (Figure 3b) shows the distribution of leverage. Leverage is measured by the ratio of total debt to market value of assets, where market value of assets is estimated as book value of total assets less book value of common equity plus market value of common equity. 


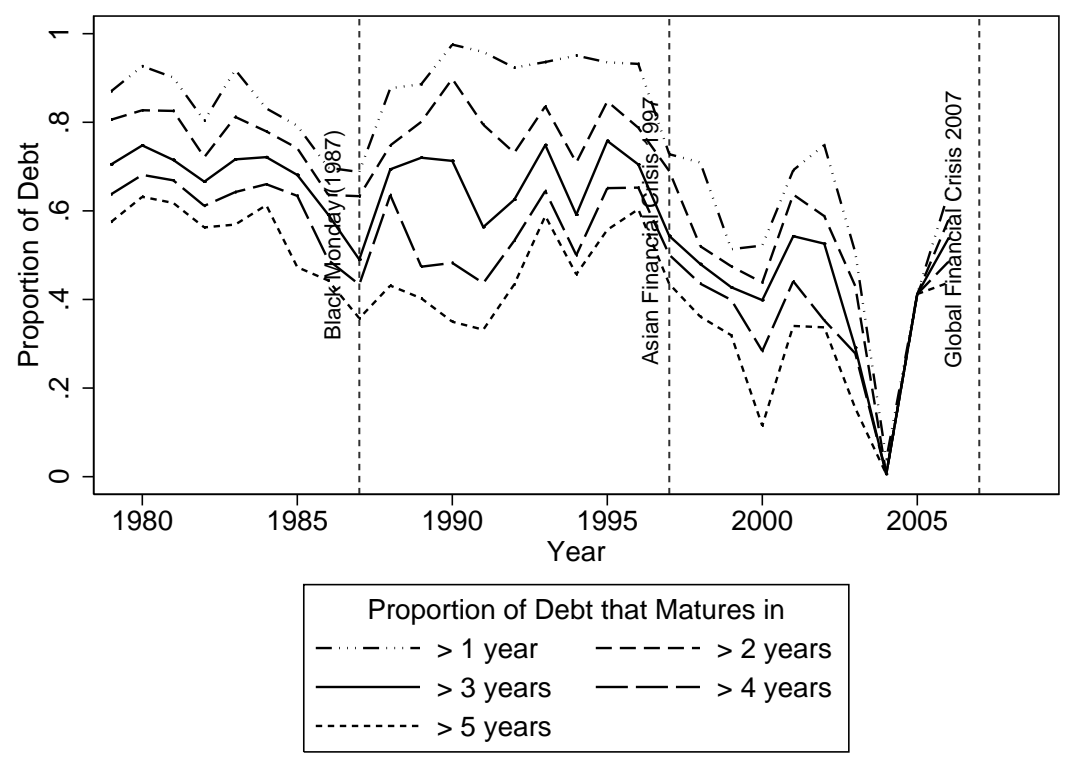

Fig. 4. Cross-sectional view of the proportion of debt that matures in more than one, two, three, four and five years from the fiscal year end for REITs.

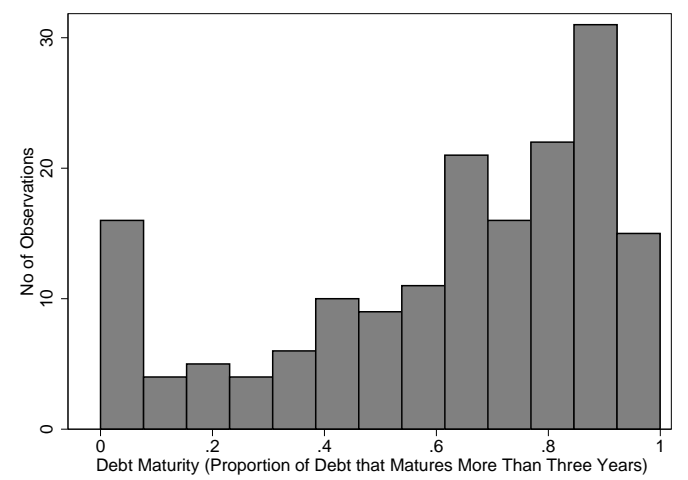

(a) Debt Maturity Histogram for REITs

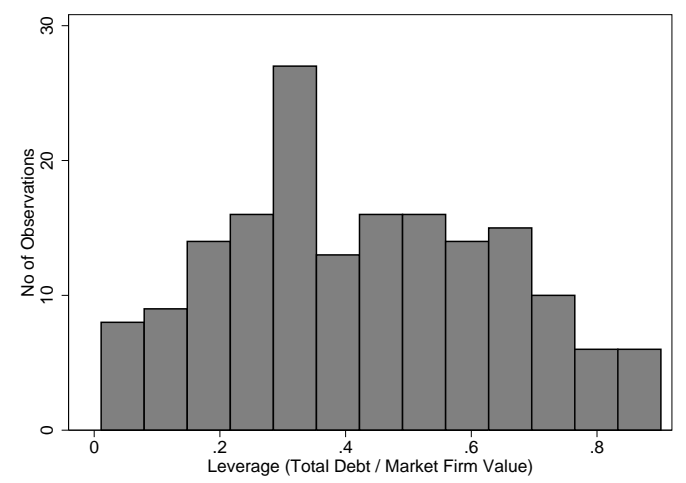

(b) Leverage Histogram for REITs

Fig. 5. Histograms of debt maturity and leverage are plotted using 189 firm-year observations for REITs over 1973 and 2006 from Compustat Database, in Figure 3a and in Figure 3b, respectively. Histogram of debt maturity (Figure 3a) shows the distribution of debt maturity, measured by the proportion of long-term debt (due more than three years) to total debt. Histogram of leverage (Figure 3b) shows the distribution of leverage. Leverage is measured by the ratio of total debt to market value of assets, where market value of assets is estimated as book value of total assets less book value of common equity plus market value of common equity. 
Risk Premium (\%) and Total Cost of Debt

\begin{tabular}{ccccccc}
\hline Debt Ratio & \multicolumn{3}{c}{ Risk Premium } & \multicolumn{2}{c}{ Total Cost of Debt } \\
\hline (Debt/Assets) & $\mathbf{1}$ & $\mathbf{2}$ & $\mathbf{5}$ & $\mathbf{1 0}$ & $\mathbf{2}$ x One Yr Z.C.B. & Two Yr Z.C.B. \\
\hline 0 & 0.0000 & 0.0000 & 0.0000 & 0.0000 & 0.2100 & 0.2100 \\
10 & 0.0000 & 0.0000 & 0.0002 & 0.0028 & 0.2100 & 0.2100 \\
20 & 0.0000 & 0.0001 & 0.0082 & 0.0288 & 0.2100 & 0.2100 \\
30 & 0.0001 & 0.0051 & 0.0530 & 0.0892 & 0.2100 & 0.2101 \\
40 & 0.0042 & 0.0482 & 0.1651 & 0.1832 & 0.2101 & 0.2111 \\
50 & 0.0570 & 0.2118 & 0.3536 & 0.3069 & 0.2113 & 0.2147 \\
55 & 0.1449 & 0.3687 & 0.4823 & 0.3759 & 0.2132 & 0.2181 \\
60 & 0.3151 & 0.5814 & 0.6268 & 0.4462 & 0.2169 & 0.2228 \\
65 & 0.6020 & 0.8700 & 0.7880 & 0.5287 & 0.2333 & 0.2292 \\
70 & 1.0528 & 1.2386 & 0.9690 & 0.6098 & 0.2480 & 0.2374 \\
75 & 1.7117 & 1.6824 & 1.1671 & 0.6964 & 0.3224 & 0.2473 \\
80 & 2.5509 & 2.2095 & 1.3740 & 0.7846 & 0.2917 & 0.2882 \\
85 & 3.6546 & 2.8190 & 1.6015 & 0.8690 & 0.3224 & 0.2728 \\
90 & 4.9944 & 3.4970 & 1.8399 & 0.9647 & 0.3580 & 0.2882 \\
95 & 6.5350 & 4.2392 & 2.0800 & 1.0608 & 0.4004 & 0.3051 \\
100 & 8.3387 & 5.0293 & 2.3326 & 1.1507 & & 0.3232 \\
\hline \hline
\end{tabular}

Table 1

The default-risk premium $(\lambda)$ and total cost of issuing zero coupon bonds (ZCB) over two years for various levels of leverage and maturity. Default risk premia are calculated using (2). Firm value is assumed to follow lognormal distribution with a standard deviation $(\sigma)$ of $30 \%$ per year and a risk free rate $(r f)$ of $10 \%$ per year. 


\section{Distribution of Corporate Debt Maturity and Descriptive Statistics of Non-REITs Characteristics, 1973-2006}

Panel A: Distribution of Percentage of Total Debt Maturing from the Fiscal Year End

\begin{tabular}{|c|c|c|c|c|c|c|c|}
\hline \multirow[b]{2}{*}{ Characteristic } & \multirow[b]{2}{*}{ Mean } & \multirow{2}{*}{$\begin{array}{l}\text { Std. } \\
\text { Dev. }\end{array}$} & \multicolumn{5}{|c|}{ Percentile } \\
\hline & & & Min & $\mathbf{2 5 ^ { t h }}$ & Median & $75^{t h}$ & $\operatorname{Max}$ \\
\hline \multicolumn{8}{|c|}{ Percent of Debt that Matures in } \\
\hline$>1$ year & 0.72 & 0.27 & 0.00 & 0.59 & 0.82 & 0.94 & 1.00 \\
\hline$>2$ years & 0.58 & 0.30 & 0.00 & 0.35 & 0.62 & 0.86 & 0.99 \\
\hline$>3$ years & 0.47 & 0.31 & 0.00 & 0.20 & 0.47 & 0.76 & 0.97 \\
\hline$>4$ years & 0.40 & 0.30 & 0.00 & 0.12 & 0.37 & 0.67 & 0.96 \\
\hline$>5$ years & 0.34 & 0.29 & 0.00 & 0.06 & 0.27 & 0.58 & 0.94 \\
\hline
\end{tabular}

Panel B: Distribution of Percentage of Total Debt Maturing from the Fiscal Year End

\begin{tabular}{|c|c|c|c|c|c|c|c|}
\hline \multirow[b]{2}{*}{ Characteristic } & \multirow[b]{2}{*}{ Mean } & \multirow{2}{*}{$\begin{array}{l}\text { Std. } \\
\text { Dev. }\end{array}$} & \multicolumn{5}{|c|}{ Percentile } \\
\hline & & & Min & $\mathbf{2 5 ^ { t h }}$ & Median & $75^{t h}$ & Max \\
\hline Firm Value (\$mil) & 245.61 & 630.09 & 0.63 & 19.72 & 51.63 & 161.96 & $8,653.05$ \\
\hline Debt Maturity & 0.47 & 0.31 & 0.00 & 0.20 & 0.47 & 0.76 & 0.97 \\
\hline Leverage & 0.40 & 0.23 & 0.01 & 0.21 & 0.39 & 0.58 & 0.89 \\
\hline Log of Asset Maturity & 3.14 & 0.81 & 0.83 & 2.66 & 3.18 & 3.60 & 5.25 \\
\hline Market-to-book & 1.42 & 0.94 & 0.54 & 0.90 & 1.08 & 1.56 & 6.18 \\
\hline Abnormal Earnings & 0.02 & 0.68 & -3.05 & -0.07 & 0.00 & 0.06 & 3.53 \\
\hline Log of Firm Value & 4.16 & 1.60 & 0.83 & 3.00 & 3.97 & 5.18 & 8.06 \\
\hline Firm Volatility & 0.06 & 0.07 & 0.00 & 0.02 & 0.04 & 0.08 & 0.40 \\
\hline Term Structure & 1.56 & 1.26 & -1.49 & 0.62 & 1.65 & 2.62 & 3.49 \\
\hline Fixed Asset Ratio & 0.46 & 0.28 & 0.02 & 0.21 & 0.45 & 0.70 & 0.95 \\
\hline Profitability & 0.08 & 0.09 & -0.27 & 0.04 & 0.08 & 0.13 & 0.30 \\
\hline \multicolumn{8}{|l|}{ Proportion of firm-years with } \\
\hline Operating Loss Carryforwards & 0.29 & 0.45 & & & & & \\
\hline Investment Tax Credit & 0.16 & 0.37 & & & & & \\
\hline Debt Rating & 0.03 & 0.18 & & & & & \\
\hline
\end{tabular}

Table 2

The table reports distribution of corporate debt maturity (Panel A) and descriptive statistic (Panel B) for 916 firm-year observations of non-REITs (non Real Estate Investment Trusts) between 1973 and 2006 from Compustat Database. Non-REITs are firms with Standard Industrial Classification (SIC) codes from 6500 to 6552. Variables are defined as: Debt Maturity is measured by the proportion of debt maturity due in more than three years. Leverage is the ratio of total debt (long-term debt plus debt in current liabilities) to market value of assets, where market value of assets is estimated as book value of total assets less book value of common equity plus market value of common equity. Log of Asset Maturity is measured by the natural logarithm of the ratio of depreciable assets to depreciation. Market-to-book is measured by the market value of assets divided by the book value of assets. Abnormal Earnings is the difference between earning per share in year $t+1$ minus earnings per share in year $t$, divided by the year $t$ share price. Log of Firm Size is measured by the natural logarithm of the market firm value in millions of dollars. Dollar values are inflation-adjusted (June 1982) using the the Producer Price Index (PPI). Firm Volatility is measured by the standard deviation of first differences in EBITDA over the four years preceding the sample year, scaled by average assets for that period. Term Structure is the difference between the month-end yields on a 10-year government bond and a 6-month government bond, matched to the month of a firm's fiscal year end. Bond yields are from the Federal Reserve Bank of St. Louis's economic database (FRED). Each of the dummy variables (operating loss carryforwards, investment tax credit and debt rating) equals 1 if the firm has its respective items, 0 otherwise. 


\section{Distribution of Corporate Debt Maturity and Descriptive Statistics of REITs Characteristics, 1973-2006}

Panel A: Distribution of Percentage of Total Debt Maturing from the Fiscal Year End

\begin{tabular}{|c|c|c|c|c|c|c|c|}
\hline \multirow[b]{2}{*}{ Characteristic } & \multirow[b]{2}{*}{ Mean } & \multirow{2}{*}{$\begin{array}{l}\text { Std. } \\
\text { Dev. }\end{array}$} & \multicolumn{5}{|c|}{ Percentile } \\
\hline & & & Min & $25^{t h}$ & Median & $75^{t h}$ & $\operatorname{Max}$ \\
\hline \multicolumn{8}{|c|}{ Percent of Debt that Matures in } \\
\hline$>1$ year & 0.80 & 0.27 & 0.00 & 0.80 & 0.93 & 0.97 & 1.00 \\
\hline$>2$ years & 0.71 & 0.28 & 0.00 & 0.62 & 0.82 & 0.91 & 1.00 \\
\hline$>3$ years & 0.62 & 0.29 & 0.00 & 0.44 & 0.71 & 0.86 & 1.00 \\
\hline$>4$ years & 0.55 & 0.29 & 0.00 & 0.34 & 0.62 & 0.79 & 1.00 \\
\hline$>5$ years & 0.48 & 0.29 & 0.00 & 0.23 & 0.51 & 0.74 & 1.00 \\
\hline
\end{tabular}

Panel B: Distribution of Percentage of Total Debt Maturing from the Fiscal Year End

\begin{tabular}{|c|c|c|c|c|c|c|c|}
\hline \multirow[b]{2}{*}{ Characteristic } & \multirow[b]{2}{*}{ Mean } & \multirow{2}{*}{$\begin{array}{l}\text { Std. } \\
\text { Dev. }\end{array}$} & \multicolumn{5}{|c|}{ Percentile } \\
\hline & & & Min & $\mathbf{2 5 ^ { t h }}$ & Median & $75^{t h}$ & $\operatorname{Max}$ \\
\hline Firm Value (\$mil) & $1,895^{* * *}$ & 3,234 & 3.70 & 102.23 & 389.63 & $2,609.36$ & $18,837.41$ \\
\hline Debt Maturity & $0.62^{* * *}$ & 0.29 & 0.00 & 0.44 & 0.71 & 0.86 & 1.00 \\
\hline Leverage & 0.43 & 0.22 & 0.01 & 0.27 & 0.42 & 0.58 & 0.90 \\
\hline Log of Asset Maturity & 3.26 & 0.91 & 0.53 & 2.93 & 3.19 & 3.84 & 5.76 \\
\hline Market-to-book & $1.26^{*}$ & 0.34 & 0.47 & 1.03 & 1.26 & 1.44 & 2.35 \\
\hline Abnormal Earnings & 0.12 & 0.74 & -1.16 & -0.02 & 0.01 & 0.05 & 5.66 \\
\hline Log of Firm Value & $6.00 * * *$ & 1.98 & 1.80 & 4.43 & 5.97 & 7.58 & 9.86 \\
\hline Firm Volatility & $0.04 * * *$ & 0.05 & 0.00 & 0.01 & 0.02 & 0.05 & 0.27 \\
\hline Term Structure & 1.59 & 1.25 & -1.49 & 0.72 & 1.65 & 2.62 & 3.42 \\
\hline Fixed Asset Ratio & $0.58 * * *$ & 0.27 & 0.00 & 0.44 & 0.64 & 0.80 & 0.96 \\
\hline Profitability & 0.09 & 0.06 & -0.12 & 0.04 & 0.09 & 0.11 & 0.29 \\
\hline \multicolumn{8}{|l|}{ Proportion of firm-years with } \\
\hline Operating Loss Carryforwards & $0.15^{* * *}$ & 0.36 & & & & & \\
\hline Investment Tax Credit & $0.24^{* *}$ & 0.43 & & & & & \\
\hline Debt Rating & $0.22^{* * *}$ & 0.42 & & & & & \\
\hline
\end{tabular}

Table 3

The table reports distribution of corporate debt maturity (Panel A) and descriptive statistic (Panel B) for 916 firm-year observations of REITs (Real Estate Investment Trusts) between 1973 and 2006 from Compustat Database. REITs are firms with Standard Industrial Classification (SIC) code of 6798. Variables are defined as: Debt Maturity is measured by the proportion of debt maturity due in more than three years. Leverage is the ratio of total debt (long-term debt plus debt in current liabilities) to market value of assets, where market value of assets is estimated as book value of total assets less book value of common equity plus market value of common equity. Log of Asset Maturity is measured by the natural logarithm of the ratio of depreciable assets to depreciation. Market-to-book is measured by the market value of assets divided by the book value of assets. Abnormal Earnings is the difference between earning per share in year $t+1$ minus earnings per share in year $t$, divided by the year $t$ share price. Log of Firm Size is measured by the natural logarithm of the market firm value in millions of dollars. Dollar values are inflation-adjusted (June 1982) using the the Producer Price Index (PPI). Firm Volatility is measured by the standard deviation of first differences in EBITDA over the four years preceding the sample year, scaled by average assets for that period. Term Structure is the difference between the month-end yields on a 10-year government bond and a 6-month government bond, matched to the month of a firm's fiscal year end. Bond yields are from the Federal Reserve Bank of St. Louis's economic database (FRED). Each of the dummy variables (operating loss carryforwards, investment tax credit and debt rating) equals 1 if the firm has its respective items, 0 otherwise. Asterisks on the means of REITs indicate whether they are significantly different from those of non-REITs. ${ }^{*},{ }^{*},{ }^{* *}$ indicate significance at the $5 \%$ level, $1 \%$ level and $0.1 \%$ level, respectively. 
Pearson Correlation Matrix Among Measures of Dependent and Independent Variables for Non-REITs

\begin{tabular}{|c|c|c|c|c|c|c|c|c|c|c|c|c|}
\hline & (1) & $(2)$ & $(3)$ & (4) & $(5)$ & $(6)$ & (7) & $(8)$ & (9) & $(10)$ & (11) & $(12)$ \\
\hline (1) Debt Maturity & 1 & & & & & & & & & & & \\
\hline (2) Leverage & $0.11 * * *$ & 1 & & & & & & & & & & \\
\hline (3) Log of Asset Maturity & $0.16 * * *$ & $0.11 * *$ & 1 & & & & & & & & & \\
\hline (4) Market-to-book & $0.09 * *$ & $-0.46 * * *$ & -0.02 & 1 & & & & & & & & \\
\hline (5) Abnormal Earnings & -0.06 & 0.03 & 0.03 & -0.03 & 1 & & & & & & & \\
\hline (6) Log of Firm Value & $0.14 * * *$ & -0.01 & -0.04 & $0.24 * * *$ & -0.03 & 1 & & & & & & \\
\hline (7) Volatility & $-0.17 * * *$ & $-0.20 * * *$ & $-0.09 * *$ & $0.10 * *$ & 0.06 & $-0.30 * * *$ & 1 & & & & & \\
\hline (8) Term Structure & 0.00 & -0.04 & 0.02 & 0.02 & 0.00 & 0.06 & 0.05 & 1 & & & & \\
\hline (9) Fixed Assets Ratio & $0.29 * * *$ & $0.14 * * *$ & $0.48 * * *$ & 0.00 & 0.06 & 0.04 & $-0.12 * * *$ & 0.05 & 1 & & & \\
\hline (10) Profitability & $0.15 * * *$ & -0.02 & $-0.10 * *$ & 0.03 & $-0.10 * *$ & $0.14 * * *$ & $-0.16 * * *$ & -0.02 & $0.14 * * *$ & 1 & & \\
\hline (11) Dummy Operating Loss Carryforward & $-0.13 * * *$ & $0.11 * * *$ & 0.03 & -0.05 & 0.02 & $-0.15 * * *$ & $0.14 * * *$ & 0.02 & $-0.15 * * *$ & $-0.14 * * *$ & 1 & \\
\hline (12) Dummy Investment Tax Credit & -0.03 & $-0.08 *$ & -0.05 & $-0.08 *$ & -0.02 & $-0.12 * * *$ & $-0.09 * *$ & $-0.15 * * *$ & 0.02 & $0.11 * * *$ & $-0.14 * * *$ & 1 \\
\hline (13) Dummy Debt Rating & 0.03 & $0.07 *$ & $-0.17 * * *$ & 0.03 & 0.04 & $0.25 * * *$ & -0.04 & 0.04 & $-0.13 * * *$ & 0.01 & 0.05 & -0.05 \\
\hline
\end{tabular}

Table 4: The table reports Pearson correlation among dependent and independent variables of leverage and debt maturity for 916 firm-year observations for non-REITs between 1973 and 2006 from Compustat Database. All variables are defined in Table 2. ${ }^{*}, * * * * *$ indicate significance at the $5 \%$ level, $1 \%$ level and $0.1 \%$ level, respectively. 
Pearson Correlation Matrix Among Measures of Dependent and Independent Variables for REITs

\begin{tabular}{|c|c|c|c|c|c|c|c|c|c|c|c|c|}
\hline & $(1)$ & $(2)$ & (3) & $(4)$ & $(5)$ & $(6)$ & $(7)$ & (8) & $(9)$ & (10) & $(11)$ & (12) \\
\hline (1) Debt Maturity & 1 & & & & & & & & & & & \\
\hline (2) Leverage & -0.09 & 1 & & & & & & & & & & \\
\hline (3) Log of Asset Maturity & $0.25 * * *$ & -0.14 & 1 & & & & & & & & & \\
\hline (4) Market-to-book & $0.19 * *$ & $-0.18 *$ & 0.13 & 1 & & & & & & & & \\
\hline (5) Abnormal Earnings & $-0.16 *$ & $0.31 * * *$ & $-0.34 * * *$ & -0.1 & 1 & & & & & & & \\
\hline (6) Log of Firm Value & $0.28 * * *$ & 0.13 & -0.03 & $0.41 * * *$ & 0.07 & 1 & & & & & & \\
\hline (7) Volatility & $-0.39 * * *$ & 0 & $-0.19 * *$ & -0.06 & $0.49 * * *$ & $-0.22 * *$ & 1 & & & & & \\
\hline (8) Term Structure & -0.08 & 0.04 & -0.12 & -0.04 & -0.03 & 0.06 & -0.08 & 1 & & & & \\
\hline (9) Fixed Assets Ratio & $0.39 * * *$ & -0.01 & $0.71 * * *$ & $0.19 * *$ & $-0.26 * * *$ & 0.12 & $-0.33 * * *$ & -0.07 & 1 & & & \\
\hline (10) Profitability & 0.12 & $-0.14 *$ & 0.14 & $0.26 * * *$ & $-0.22 * *$ & 0.04 & -0.14 & -0.14 & $0.17 *$ & 1 & & \\
\hline (11) Dummy Operating Loss Carryforward & -0.02 & 0.1 & 0 & -0.14 & -0.06 & $-0.19 * *$ & 0.02 & -0.12 & -0.01 & -0.12 & 1 & \\
\hline (12) Dummy Investment Tax Credit & $0.33 * * *$ & $-0.20 * *$ & -0.01 & 0.04 & -0.08 & -0.01 & $-0.17 *$ & -0.07 & -0.01 & 0.01 & $-0.24 * * *$ & 1 \\
\hline (13) Dummy Debt Rating & 0.12 & 0.12 & -0.14 & 0.13 & $0.26 * * *$ & $0.57 * * *$ & 0.02 & -0.02 & 0 & -0.03 & -0.05 & $-0.18 *$ \\
\hline
\end{tabular}

Table 5: The table reports Pearson correlation among dependent and independent variables of leverage and debt maturity for 189 firm-year observations for REITs between 1973 and 2006 from Compustat Database. All variables are defined in Table 2. ${ }^{*},{ }^{* *},{ }^{* * *}$ indicate significance at the $5 \%$ level, $1 \%$ level and $0.1 \%$ level, respectively. 
Three-stage Least Squares Regression Results

\begin{tabular}{|c|c|c|c|c|c|c|}
\hline \multirow[b]{2}{*}{ Variables } & \multicolumn{2}{|c|}{ Predicted sign } & \multicolumn{2}{|c|}{ Non-REITs } & \multicolumn{2}{|c|}{ REITs } \\
\hline & Leverage & Maturity & Leverage & Maturity & Leverage & Maturity \\
\hline Leverage & & $(+)$ & & $\begin{array}{c}0.653^{* *} \\
(0.21)\end{array}$ & & $\begin{array}{c}-0.063 \\
(0.22)\end{array}$ \\
\hline Debt Maturity & $(+)$ & & $\begin{array}{c}-0.004 \\
(0.10)\end{array}$ & & $\begin{array}{c}-0.222^{*} \\
(0.11)\end{array}$ & \\
\hline Log of Asset Maturity & & $(+)$ & & $\begin{array}{c}0.037^{* *} \\
(0.01)\end{array}$ & & $\begin{array}{l}0.009 \\
(0.02)\end{array}$ \\
\hline Market-to-book & $(-)$ & $(-)$ & $\begin{array}{c}-0.113^{* * *} \\
(0.01)\end{array}$ & $\begin{array}{c}0.104^{* * *} \\
(0.03)\end{array}$ & $\begin{array}{c}-0.129^{*} \\
(0.05)\end{array}$ & $\begin{array}{l}0.022 \\
(0.06)\end{array}$ \\
\hline Abnormal Earnings & $(+)$ & $(-)$ & $\begin{array}{l}0.002 \\
(0.01)\end{array}$ & $\begin{array}{c}-0.021 \\
(0.01)\end{array}$ & $\begin{array}{c}0.109^{* * *} \\
(0.02)\end{array}$ & $\begin{array}{l}0.002 \\
(0.04)\end{array}$ \\
\hline Log of Firm Value & $(-)$ & $(+)$ & $\begin{array}{l}0.007 \\
(0.00)\end{array}$ & $\begin{array}{l}0.006 \\
(0.01)\end{array}$ & $\begin{array}{c}0.025^{* *} \\
(0.01)\end{array}$ & $\begin{array}{c}0.066^{* * *} * \\
(0.01)\end{array}$ \\
\hline Volatility & $(-)$ & $(-)$ & $\begin{array}{c}-0.491^{* * *} \\
(0.11)\end{array}$ & $\begin{array}{c}-0.310 \\
(0.19)\end{array}$ & $\begin{array}{c}-1.120^{* *} \\
(0.42)\end{array}$ & $\begin{array}{c}-1.390^{* *} \\
(0.44)\end{array}$ \\
\hline Term Structure & & $(+)$ & & $\begin{array}{l}0.004 \\
(0.02)\end{array}$ & & $\begin{array}{l}0.000 \\
(0.03)\end{array}$ \\
\hline Debt Rating Dummy & & $(-)$ & & $\begin{array}{l}0.028 \\
(0.06)\end{array}$ & & $\begin{array}{l}0.079 \\
(0.05)\end{array}$ \\
\hline Fixed Assets Ratio & $(+)$ & & $\begin{array}{c}0.151^{* * *} \\
(0.04)\end{array}$ & & $\begin{array}{l}0.097 \\
(0.07)\end{array}$ & \\
\hline Profitability & $(-)$ & & $\begin{array}{c}-0.009 \\
(0.08)\end{array}$ & & $\begin{array}{c}-0.065 \\
(0.24)\end{array}$ & \\
\hline Operating Loss Carryforwards Dummy & $(-)$ & & $\begin{array}{c}0.048^{* *} \\
(0.02)\end{array}$ & & $\begin{array}{l}0.062 \\
(0.04)\end{array}$ & \\
\hline Investment Tax Credit Dummy & $(-)$ & & $\begin{array}{c}-0.064^{* * *} \\
(0.02)\end{array}$ & & $\begin{array}{c}-0.049 \\
(0.04)\end{array}$ & \\
\hline Constant & & & $\begin{array}{c}0.492^{* * *} \\
(0.04)\end{array}$ & $\begin{array}{c}-0.067 \\
(0.14)\end{array}$ & $\begin{array}{c}0.566^{* * *} \\
(0.08)\end{array}$ & $\begin{array}{c}0.506^{* *} \\
(0.19)\end{array}$ \\
\hline Observations & & & 916 & 916 & 189 & 189 \\
\hline$R^{2}$ & & & 0.279 & 0.034 & 0.195 & 0.544 \\
\hline Year Dummies & & & No & Yes & No & Yes \\
\hline Pagan-Hall statistic (p-value) & & & 0.984 & 0.266 & 0.140 & 0.071 \\
\hline
\end{tabular}

Table 6

The table shows the three-stage least squares regression results with the coefficients for the explanatory variables (standard errors). The regression results are based on 916 (189) firm-year observations for nonREITs (REITs) over the period of 1973 to 2006. The Pagan-Hall test (p-value) examines the null hypothesis that error terms are homoscedastic. 